\title{
TOWARDS NORMATIVE CONSENSUS ON RESPONSIBILITY TO PROTECT
}

\author{
Teresa Chataway"
}

Responsibility to protect ( $R 2 P$ ) is a concept advanced by the International Commission on Intervention and State Sovereignty, and the theme of The Responsibility to Protect Report (2001). ${ }^{1}$ It is based on the argument that states, and failing them the international community, have the responsibility to protect the human dignity and rights of people everywhere. The incremental normative consensus attained by the R2P concept is revealed by paras 138-39 in the Outcome Statement of the UN 2005 General Assembly Summit, and is reaffirmed in UN Security Council Resolution 1674. Security Council Resolution 1706 called for the deployment of UN peacekeepers in Darfur by applying, for the first time, the R2P principle to a particular context. This essay begins by outlining the background to the R2P norm. Second, the etymology of R2P is addressed. Third, a life-cycle analysis contextualises R2P as an emerging international norm. Fourth, the crucial role played by civil society organisations is outlined. Finally, the operationalisation of the R2P norm is discussed with respect to the Darfur humanitarian tragedy. In the light of this and past conscience-shocking mass human rights violations, our common humanity demands that the R2P's three key elements should prevail over statist values and interests. Ultimately, state practice will enable the ripening of R2P into a rule of customary international law and an effective instrument for the protection of human dignity and rights.

\section{Background to R2P}

The individual is the basis on which every free, democratic society is built. As a result, we increasingly conceive of sovereignty as involving the responsibility of States, in the first instance, to protect their own

Adjunct Research Fellow, Socio-Legal Research Centre, Griffith University; the SLRC supported the initial research on R2P with a Small Grant.

1 International Commission on Intervention and State Sovereignty (ICISS), The Responsibility to Protect (Ottawa International Development Research Centre 2001). Available at http://iciss.ca/report-en.asp (hereinafter R2P Report). The ICISS comprised 12 commissioners with diverse regional backgrounds, views and perspectives. It was co-chaired by Gareth Evans and Mohamed Sahnoun. Besides the commission meetings, there were 11 regional roundtable gatherings and national consultations to allow for the broadest range of opinions to be heard. 
populations. When that protection is lacking, all of us in the international community share responsibility to protect our fellow human beings from massive and systematic violations of human rights, wherever and whenever they occur. (UN Secretary-General Kofi Annan, 9 March 2004) ${ }^{2}$

While the conflicts in Afghanistan, Iraq and the Middle East continue unabated, the need to reconceptualise the problem of intervention is increasingly more evident. Hence, 'thinking through responsibility, in terms of both the juridical and ethical claims made upon us, ought to be one of the key tasks of our intellectual [and practical] times'.

World War I, regarded generally at the time as the war to end all wars, was instead followed by another, which inflicted even more extreme forms of cruelty and suffering upon humanity. These conflicts claimed millions of lives, and remain a continual reminder of the absolute futility of war. World War III has not yet eventuated. May we perhaps surmise that the earth's powerful leaders are cognisant that were this to occur today, the death of 50 million people, or the total number that perished during those prolonged years of conflict in different continents, and the slaughter of innocents perpetrated as a result of inhuman ideologies, would only take a few minutes? Significantly, this would only be the beginning of the massacre that would undoubtedly mark 'the fate of the earth'. ${ }^{4}$ In the Millennium Declaration, UN Member states were described as 'the indispensable common house of the entire human family'. The concern for humankind is generic to the UN foundational premise.

The issue of 'Rights and Responsibilities' is discussed in the R2P Report, where Section $(C)$ in the Supplementary Volume is devoted to 'Morality, Law, Operations and Politics'. R2P extends to a continuum of obligations: to prevent, to react and to rebuild. Although initially most commentaries on the report did not address this more encompassing rationale for R2P, gradually greater attention is being devoted to it. Action rather than rhetoric is paramount, particularly in the light of past gross violations of human rights, ethnic cleansing, genocide and crimes against humanity, and new threats to national and collective security. States must be accountable for the protection of their citizens, including when they themselves are the perpetrators of abuse. The recurrence of devastating intrastate conflicts has prompted reconsideration of both the social and legal meaning of responsibility. The emerging norm of R2P encapsulates a clearer meaning of a state's obligations.

2 SG/SM/9190, "Canada "Pillar of Support" for UN Leader in Promoting Peaceful, Global Governance', Address to Canadian Parliament, Ottawa, 9 March 2004.

3 Mills and Jenkins (2004), p 5.

4 Schell (1982), p 119, who outlines the meaning and perils of nuclear war. One of the most compelling sentences is 'Death is only death; extinction is the death of death'.

5 Secretary-General's address to the General Assembly, New York, 21 September 2004. See generally, UN member states' R2P-related statements, General Debate of the $59^{\text {th }}$ Session of the General Assembly, September 2004. 
The notion of responsibility towards others has a long intellectual pedigree. Mary Robinson, the former UN High Commissioner for Human Rights, considers that a 'feeling of being answerable' alerts us to the fact that we are responsible for the rights of others, and not just our own. ${ }^{6}$ Horace Kallen expressed the same notion as: "His/her "youness" will ensure that he/she "feels responsible" and "answerable", and will defend that vantagepoint "against all attacks"'? More recently, Paula Keating, in a discussion where she links Kant and Derrida on the notion of hospitality and 'this feeling that I am involved', 8 observes that the challenge of 'impossible hospitality sets us a task to perform as a morally responsive subject'.

The responsibility to protect all individuals lies at the fault-line between the international system's commitment to state autonomy and integrity, respect for human dignity and the protection of human rights. R2P as a norm reasserts the responsibility or the obligation of states to protect their citizens, both within and beyond their national borders, under the umbrella concept of the common heritage of mankind in international law. ${ }^{10}$ By contrast, the non-

6 Royal Palace Amsterdam, Ceremony of the Erasmus Prize, 9 November 1999, Address by Mary Robinson, UN High Commissioner for Human Rights, p 3, www.unhchr.ch/huricane/huricane.nsf/0/BB5A38006517BE1 18025682D00357E2 C

$7 \quad$ Kallen (1942), p 363.

$8 \quad$ Keating (2004), p 1.

$9 \quad$ Keating (2004), p 8, original emphasis.

10 Use of this terminology is deliberate, with a wider connotation than that used by the Maltese Arvid Pardo, who proposed to the UN that the oceans should be declared to be the 'Common Heritage of Mankind', UN/GA Res. 2749 (XXV), 17 December 1970, Declaration of Principles Governing the Seabed and the Ocean Floor, and the Subsoil Thereof, beyond the Limits of National Jurisdiction. See Rao (1975), specifically note 31 , p 238, and notes 50-53, pp 241-42. The concept is used here in the wider sense expressed by Radbruch (1936): 'The great danger of pure compromise - a fatal danger for international equity - is unavoidable in a world dominated by national interests, where the idea of the common good of the international community has not sufficient authority. An Equity Tribunal can only come into being when on the one hand judges can be found who will without hesitation subordinate the interests even of their own nation to the common good of the world and when on the other an international mind has developed in every community which will support, echo and authorize such decisions. We are further than ever from such conditions - unless the world catastrophe which threatens us can at the last moment bring those responsible to their senses.' Radbruch (1936), p 13 See generally Baslar (1988). A linkage between common heritage of mankind and dictates of public conscience is made in the Darfur hecatomb discussion below.

The public conscience is considered a real concept in international humanitarian law. Its usage was incorporated as 'dictates of public conscience' in the 'Martens Clause'. The clause was 'originally designed to provide residual humanitarian rules for the protection of the population of occupied territories, especially armed resisters in those territories' (Meron, 2000), p 79. Over time, the 
intervention norm, as provided by Chapter VII of the UN Charter, has been used by states to guard against external military force that would interfere in both their domestic affairs and the treatment of their people. In light of the experience of intrastate conflicts during the 1990s, it is important to ascertain the level of receptivity of the $\mathrm{R} 2 \mathrm{P}$ concept both nationally and internationally. Data reveal that an ever-increasing global consensus on human rights protection is apparent at many levels of civil society. However, it is also evident that failure to address the persisting contradiction between the principle of respect for the human dignity of every person and the entrenched norm of non-interference related to state sovereignty can severely undermine the emergence of a new international norm. of R2P:

The following is a summary of events leading to the definitive concept

1 Secretary-General Kofi Annan made two major statements during 1999, one in the media and the other in the General Assembly, in which he underscored the equal importance of individual and State sovereignty principles. ${ }^{11}$ In his Millennium Report, he appealed to the international community to seek a new consensus that could resolve the conflict between state sovereignty and the moral obligation to protect all peoples against gross violation of their human dignity and basic rights.

2 Those statements motivated the Canadian government to establish ICISS to consider ways in which a new international consensus on more appropriate responses by the international community to mass violations of human rights and threats to security could be achieved. The outcome, as articulated in the R2P report, introduced a distinct shift from the established non-intervention norm, and signalled a novel approach to the application of 'provisions concerning human dignity'. Moreover, the report redefined the policy dilemma set up by the state sovereignty/humanitarian intervention debate by reasserting that states have the responsibility, and by default the international community, to protect all individuals whose human dignity and fundamental rights are at risk. From this perspective, then, the R2P concept is a distinct development in the history of human rights since the adoption of the Universal Declaration of Human Rights, and comprises the following three key elements:

(a) Responsibility to prevent aims to address both the root and direct causes of internal conflict and other man-made crises that place populations at risk.

(b) Responsibility to react aims to respond to situations of compelling human need with appropriate measures, which may include coercive measures like sanctions and international prosecution, and in extreme cases military intervention.

clause has been understood to extend to all areas of international humanitarian law See also Eyffinger (1999); Miyazaki (1984); Pustogarov (1999, 2000).

11 See UN GA/9595 20 September 1999, and his controversial 'Two Concepts of Sovereignty', The Economist, 18 September 1999. 
(c) Responsibility to rebuild aims to provide, particularly after military intervention, full assistance with recovery, reconstruction and reconciliation, and to address the causes of the harm the intervention was designed to halt or avert.

3 In the wake of such devastating and destabilising events as $9 / 11$, and the wars in Afghanistan and Iraq, there was a general perception by several states that the UN was incapable of discouraging the growing unilateralism with respect to collective security. Proclaimed ambivalent interpretations of international law on the ongoing wars exacerbated the situation. The Secretary-General responded by appointing a High-level Panel on Threats, Challenges and Change ( 3 November 2003). The High-level Panel's task was to 'examine the major threats and challenges the world faces in the broad field of peace and security, including economic and social issues insofar as they relate to peace and security, and make recommendations for the elements of a collective response'. In its report, A More Secure World: Our Shared Responsibility, delivered on 2 December 2004, the High-level Panel advanced the principle of 'our shared responsibility to protect' to deal with the collective security issue, and made other recommendations for UN reform. ${ }^{12}$ The political reality is that such statements as 'no more Rwandas' and 'the glacial speed to assist Darfur' will recur unless a more democratic Security Council makes timely and appropriate decisions for conflict resolution. Failure to act will in the end result in the international community remaining at 'the fork in the road', so described by the Secretary-General on 23 September 2003. As worthy as $A$ More Secure World was, the major stumbling block to be faced remains the power of veto-holding seats in the Security Council, and the way that power is at times used or misused. A More Secure World endorses the idea of a collective responsibility to protect civilians from genocide, ethnic cleansing and other comparable atrocities. It also stresses that when a state fails to protect its citizens, the international community is obliged to act, through humanitarian operations, monitoring missions, and diplomatic pressure - and with force if necessary, but always as a last resort. By the end of 2004, relatively little analytical reporting of $A$ More Secure World appeared in the media. The sample available reflects both the positive and cynical views. Beneath the header 'Good Diagnosis but Poor Prescription, Human Rights Watch ${ }^{13}$ supported the five criteria of legitimacy laid out in the High-level Panel's Report, but criticised the lack of reference to international humanitarian law as the indispensable guiding principle of any military action. The Sunday Herald (Scotland) observed that the Security Council "has shown itself to be toothless in the face of the

12 See UN GA/59/565 A More Secure World: Our Shared Responsibility. Report of the High-level Panel on Threats, Challenges and Change, 2 December 2004.

13 'UN: Good Diagnosis, but Poor Prescription', Human Rights Watch, 2 December 2004. 
humanitarian tragedy in Darfur and it allowed itself to be emasculated over Iraq'. ${ }^{14}$ Upon the Secretary-General's presentation of $A$ More Secure World to the General Assembly, its then President Jean Ping (Gabon) remarked that the standing ovation given to the SecretaryGeneral was 'a rare and valuable homage', and 'The SG and his works on behalf of the Organization have been touchstones for the peoples of the world. The Assembly is ready to begin tackling the Panel's proposals. ${ }^{15}$ By contrast, there was the following mid-west US reaction: 'There is not much time left for the United Nations to right itself. With conservative politics on the rise in the United States, Washington could pull the plug by all but abandoning the joint. Yes, the United Nations could fade away. And if it does, under conditions of terminal incompetence and corruption, who would really care? ${ }^{16} \mathrm{~A}$ similar array of positive and negative comments continued during 2005 as $A$ More Secure World was considered and acted upon.

4 The Secretary-General's response to A More Secure World in March 2005, titled In Larger Freedom, includes the recommendation for a rules-based international order with the responsibility to protect human dignity as its central theme. ${ }^{17}$ In May 2005, UN member states participated in informal thematic consultations on the 'Freedom to live in Dignity'. The outcomes were distilled into the 'Draft Outcome Document of the High-level Plenary Meeting of the General Assembly' for the UN World Summit in September 2005, at which time further consideration of the R2P concept was recommended.

5 The inclusion of R2P as an emerging norm in the UN 2005 Summit Outcome Statement ${ }^{18}$ is considered a positive step towards effective protection of human dignity and basic rights. The relevant text in that statement is in paragraphs 138 and $139 .{ }^{99}$ Such endorsement reflects the international community's increased realisation that new strategies

14 'Annan Under Attack, but the Real Target is the Idea of a Powerful UN', Sunday Herald (Scotland), 5 December 2004.

15 Press Release GA/10314 'S-G Underscores Urgency of Implementing Reform as He Introduces High-level Panel's Report to General Assembly', 8 December 2004.

16 'Righting the United Nations', The Seattle Times, 8 December 2004.

17 See Executive Summary, www.un.org/largerfreedom/Summary.html.

18 Available at www.un.org/summit2005/Draft_Outcome130905.pdf, paras 138 and 139.

19 Para 138 reads: 'Each individual State has the responsibility to protect its populations from genocide, war crimes, ethnic cleansing and crimes against humanity.' Para 139 reads that world leaders 'are prepared to take collective action, in a timely and decisive manner, through the Security Council, in accordance with the UN Charter, including Chapter VII, on a case by case basis and in cooperation with relevant regional organizations as appropriate, should peaceful means be inadequate and national authorities manifestly failing to protect their populations from genocide, war crimes, ethnic cleansing, and crimes against humanity and its implications, bearing in mind the principles of the Charter and international law'. 
are essential to prevent gross violations of human dignity and human rights both within and beyond state boundaries.

6 On 28 April 2006, Security Council Resolution 1674 'Reaffirm[ed] the provisions of paragraphs 138 and 139 of the 2005 World Summit Outcome Document regarding the responsibility to protect populations from genocide, war crimes, ethnic cleansing and crimes against humanity'. ${ }^{20}$

7 On 31 August 2006, Security Council Resolution 1706 called for the deployment of UN peacekeepers to Darfur by applying the R2P principle to a particular context for the first time. ${ }^{21}$ The Security Council 'invited' Sudan to consent to the deployment of UN troops in a hybrid arrangement with the force established by the African Union. Such action with reference to R2P should alert Khartoum that, while the Security Council seeks the government's cooperation, the international community is prepared to step in if Sudan will not or cannot fulfil its sovereign responsibilities. It is historically significant that Ghana's representative retreated from the traditional position prevailing within the Organization of African Unity (the African Union's predecessor) of rejecting outside interference. Here we witness one African state, Ghana, supporting outside intervention in another African state, Sudan. This shifting position on sovereignty is not limited to Africa. Burma's Asian neighbours are no longer prepared to shelter the Burmese generals. Some major Latin American countries have also embraced the limited-sovereignty principle. These developments enhance the potential of R2P to become a broadly accepted international norm, which can subsequently ripen into a rule of customary international law. According to Gareth Evans, R2P is unfinished business. He identifies the following tasks for consolidation: we must hold the line against backsliding, make absolutely clear the limits of military action, solve the problem of capacity, be geared up to campaign worldwide for effective action as new situations within the scope of the R2P norm arise, and build a new international campaign structure to politically advance the R2P agenda. In his view, successful outcomes for these tasks will depend on good arguments, intelligently and energetically advanced. Inevitably, the interrelated perspectives of this argumentation will be dominated by institutional concerns, states' national interest, and financial and moral/ethical issues. ${ }^{22}$ It is argued throughout this essay that these need to be complemented by the exercise of an

Available at www.un.org/docs/sc/unsc_resolutions06.html, on 'Protection of Civilians in Armed Conflict'.

21 Available at www.un.org/docs/sc/unsc_resolutions06.html, on 'Reports of the Secretary-General on the Sudan'.

22 'Making Idealism Realistic: The Responsibility to Protect as a New Global Security Norm', address by Gareth Evans, President of the International Crisis Group and Co-Chair of the International Commission on Intervention and State Sovereignty, to launch Stanford MA Program in International Policy Studies, Stanford University, 7 February 2007. 
international mind, due respect for human dignity, and greater recognition of the type of inclusiveness that cosmopolitical democracy can afford to all human beings.

The dissemination of the R2P Report is characterised by four features: speeches by Commission members; specific institutional conferences, academic seminars and research studies on the concept; focused studies by global civil society organizations (CSOs), which sought to examine the validity, efficacy and potential of the concept to evolve as a norm. Some other institutional responses are detailed in the references below. The following four observations reveal how these approaches contributed to the progression of $\mathrm{R} 2 \mathrm{P}$ as an emerging norm in international law, and its operationalisation.

First, research papers discussing the theory that underpins R2P, and approaches to its operationalisation have been well received. Evans can be singled out for his global contribution as a 'norm entrepreneur ${ }^{23}$ In London's Financial Times, it was acknowledged that R2P marked a 'profound shift in international law and its success was due in no small part to the advocacy of Gareth Evans' ${ }^{24}$ His addresses focus on reminding audiences of three major themes: that 'there must be no more Rwandas'; that overcoming 'the scourge of conflict and mass violence can only ultimately be achieved through a wholly cooperative approach'; and that the timely recognition of the R2P norm should be regarded as a feature of international law. He argues that "with perseverance and application and declaratory resolutions, guidelines can become norms, and norms can become accepted principles of customary international law, even if they never see the light of day as treaty or Charter provisions' ${ }^{25}$

23 Evans' 2004 papers include the following: 'Shifting Security Parameters in the 21st Century', paper delivered to Emirates Center for Strategic Studies and Research (ECSSR) $9^{\text {th }}$ Annual Conference - The Gulf: Challenges of the Future, Abu Dhabi, 12 January 2004; 'Banishing the Rwanda Nightmare: The Responsibility to Protect', PBS Frontline, 31 March 2004; 'Uneasy Bedfellows: "The Responsibility to Protect" and Feinstein-Slaughter's "Duty to Prevent", Commentary on Lee Feinstein and Anne-Marie Slaughter, 'The Duty to Prevent', Foreign Affairs, Jan/Feb 2004, at ASIL Conference, Washington DC, 1 April 2004; 'Security Threats, Challenges and Change: The UN Secretary General's High-level Panel', Notes for Introductory Presentation to NZ/MFA Forum on UN and Global Security, Wellington, 1 September 2004; 'No More Rwandas or Darfurs: The International Responsibility to Protect', Address by President of the International Crisis Group to Sydney Peace Foundation, University of Sydney, 3 September 2004; 'A World Without Conflict: How Donors Can Make a Difference', Keynote Address to Chicago Global Donors Network, 2nd Annual Conference on International Giving, Chicago, 5 October 2004. His 2005-07 papers continue the R2P advocacy, and call for action, not just words, and undertaking the unfinished business.

24 Cited in 'Gareth Who?' where Emma-Kate Symons describes Gareth Evans as 'a poster boy for international peace', Weekend Australian Magazine, 1819 February 2006, p 24.

25 Evans' paper (2004) 'Shifting Security Parameters in the 2 Ist Century', emphasis added. 
Second, numerous conferences and plenary sessions were held in most world regions. The Canadian government has been catalytic in advancing the R2P agenda. In 2002, the International Peace Academy, the UNU/Canadian Government, Science for Peace, and Pugwash Canada held a range of seminars, and the operational dimension in particular was addressed by Project Ploughshares. A seminar by experts produced a challenging report. ${ }^{26}$ It recognises that many of the possible diplomatic measures to broaden international adherence to the principles advanced in R2P Report are difficult to implement because the present institutional order lacks effective checks and balances on the use of force for humanitarian purposes. These experts also acknowledge the role played by global CSOs in conflict prevention, and recommend their increased engagement in the work of the Security Council. The R2P Report was considered at Heads of Government level in the United Kingdom in late 2002, and the Security Council discussed it at a two-day forum retreat in May 2002. ${ }^{27}$ These seminars reveal the broad range of efforts in promoting acceptance of the R2P first as a concept and then as an international norm at both government policy and implementation levels.

Third, such global organizations as the-World Federalist Movement developed a specific R2P-Civil Society Project to encourage prompt action in large-scale humanitarian crises. The project aims to contribute to the development of robust norms to ensure the international community responds earlier and more effectively to emerging situations with potential for massive loss of life. The first phase of the project has been successfully completed. ${ }^{28}$ The process of liaising with civil society partners to deepen the debate, to promote international norm formation, and to monitor responses by states, the Security Council and other international bodies, is continuing.

Fourth, a Canadian Non-Paper on The Responsibility to Protect and the Evolution of the United Nations' Peace and Security Mandate was submitted to the High-level Panel for consideration. ${ }^{29}$ The panel provided an excellent opportunity for clarifying to the international community its responsibility to protect civilians from the worst threats to their physical security, should states default in their obligation. This non-paper recognises the Security Council's ad hoc procedure in dealing with intrastate conflict and the resultant deleterious impact on civilians. The submission calls for clearer guidelines on the

26 The Operational Dimensions of Intervention, a report of a 5-6 September 2002 Project Ploughshares seminar organised in association with the Pearson Peacekeeping Centre. Participants from the Department of National Defence, Department of Foreign Affairs and International Trade, and the Canadian International Development Agency as well as civil society explored the operational dimensions of the ICISS report.

27 For forum outcomes, see articles in (2003) 7 International Journal of Human Rights.

28 'An Overview of the Responsibility to Protect - Civil Society Project', World Federalist Movement-Institute for Global Policy, January 2004.

29 See 'Canadian Non-Paper on The Responsibility to Protect and the Evolution of the United Nations', Peace and Security Mandate: Submission to the UN Highlevel Panel on Threats, Challenges and Change (nd, but 2004). 
responsibility for international protection, failing which the Security Council's performance will continue to be measured against contradictory standards. This modality leaves the Security Council vulnerable to charges of ineffectiveness from all sides, increasing the likelihood that intervention will be undertaken without its authorisation, and questioning its primacy in resolving issues of peace and security. This is aptly illustrated by the circumstances relating to the United States-led 'coalition-of-the-willing' invasion of Iraq in 2003.

It is important for the international community to speak in unison and assertively on the acceptance of R2P as a new international norm. One such example is represented by paras 138-39. Based on the extensive data emerging from the Darfur conflict examined below, it is evident that no single initiative has so far succeeded. It may well be that the level of normative consensus attained by R2P can provide the necessary impetus for all the relevant parties to coordinate their efforts at diplomacy, policy, advocacy and, most importantly, international political will to achieve a resolution of this conflict.

\section{R2P Etymology from Philosophical Perspectives}

This etymology of R2P begins by defining the terms. It then briefly outlines the perspectives of Kallen, Levinas, Derrida, Kant, Ricoeur and Allott, discusses the institutional responses and declaratory statements, and analyses such statements to discern both individual and collective action. The R2P report draws on the philosopher Isaiah Berlin's view for its starting point, as encapsulated by the following excerpt:

[Our] network of beliefs and practices on which all current morality seems to me to depend, presupposes the notion of responsibility, and responsibility entails the ability to choose between black and white, right and wrong, pleasure and duty; as well as, in a wider sense, between forms of life, forms of government, and the whole constellation of moral values in terms of which most people, however much they may or may not be aware of it, do in fact live. ${ }^{30}$

Yet most of the literature that discusses R2P generally assumes 'responsibility' is a given. According to the Oxford English Dictionary (OED), 'responsibility' means 'the state or fact of being responsible; authority; the ability to act independently and make decisions; the person or thing for which one is responsible'. Frederic Bastiat contends that: 'For man responsibility is everything! It is his motive force, his teacher, his rewarder and punisher. Without responsibility man no longer has free will, he is no longer perfectible, he is no longer a moral being, he learns nothing, and he is nothing. He falls into inertia and no longer counts except as a unit of the herd. ${ }^{31}$ The OED renders the meaning of the term 'protect' as 'to keep safe; defend; guard; shield'. Hugo Grotius expresses his particular concern for individuals in civil

\footnotetext{
30 Berlin (1998), p 60.

31 Bastiat (1849) [1996 edn.], Ch 17, para 45.
} 
society thus: 'Individual citizens should not only refrain from injuring other citizens, but should furthermore protect them, both as a whole and as individuals. ${ }^{32}$ Writing in a similar vein on the issue of protection at the end of World War I, the publicist AJ Jacobs remarked that 'personal safety and social peace depend upon the practice of mutual protection, without which no justice could be administered, and national safety and international peace must be based upon that same principle'. ${ }^{33}$

Proceeding from Berlin's cornerstone view of responsibility, the R2P report advances the argument that the symbiosis between responsibility and choice is central to human action. Moreover, the principle of responsibility entails fundamental moral reasoning, and challenges social and international relations theory. ${ }^{34}$ Also relevant to the present discussion are two branches of law: international humanitarian law and customary international law.

Responsibility and protection have been addressed by many philosophers over time. To begin with, Horace Kallen observes that there are manifestations of responsibility in any situation involving the processes of conflict and cooperation among human beings. ${ }^{35}$ For him, a theory of responsibility is a reflection of the social condition that creates it. Kallen posits that responsibility is universal only as a word. But actual responsibility is ambivalent both from the standpoint of those individuals who are held, or who themselves feel, responsible, and from the standpoint of those who need a response. He adds that, regardless of what particular traits identify one, or whether one belongs to different and overlapping classes and associations, these may locate one, but they do not reveal one's 'youness' ${ }^{36}$ Society defines responsibility within the framework of its mobile structure and multiple processes, and sets the parameters for individuals. The critical issue for any individual is to find a suitable vantage-point within society's structure and processes through which they can harmonise their responsibility to themselves and for others. ${ }^{37}$ The essentials of responsibility arise wherever humans make claims upon each other. To take responsibility means to admit a claim, and accept an obligation. While taking responsibility may be forced or free, its validity cannot be decided in advance. Ultimately, validity lies in the conscience of the individual, to whom we ascribe the specific vantage-point for their singularity and struggle. ${ }^{38}$ It remains axiomatic that an individual

\footnotetext{
32 Tuck (1999), p 87.

33 Jacobs (1917) p 13, original emphasis.

34 ICISS, Supplementary Volume (2001), p 129.

35 Kallen (1882-1974), a Jewish-American philosopher whose work was influenced by Kant's writings, contends as follows: 'An international order which should establish and keep secure the safety and well-being of the peoples of the different nations, would rest on a union of the nations and on laws agreed to by those nations which pledge and seek to procure for each party to the union that parity of liberty and right which democratic states pledge and seek to secure for each of their individual citizens.' (1948), p 24.

36 Kallen (1942), p 361.

37 Kallen (1942), p 363.
} 
needs to be free to act, since for Kallen: 'The root of responsibility is equal liberty. ${ }^{39}$

Emmanuel Levinas provides us with another perspective on 'responsibility for the Other' ${ }^{40} \mathrm{He}$ contends that: 'The condition for, or the unconditionality of, the self does not begin in the auto-affection of a sovereign ego that would be "compassionate" towards another person after the event. Quite the contrary. ${ }^{41}$ We have to negotiate that responsibility within ourselves. The self begins with 'compassion' for the Other, acknowledging that person's finitude and uniqueness. It is that continuing self-responsibility for the Other's uniqueness that moves one to act beyond, with meaningful projects open to the future. At times Levinas extends this responsibility for the Other by saying that we are 'responsible for what they do or suffer, ${ }^{42}$ To prevent unnecessary suffering, one must act responsibly for oneself by acting responsibly for others. As compassion for others, such responsibility supports humanitarian and liberal democratic principles and practices. ${ }^{43}$ In practice, however, democratic governments often weaken these principles. Hegemonic ambitions, imperialist tendencies, positional power, and liberal-capitalist pursuits can smother the sense of responsibility towards the uniqueness, the independence and welfare of the Other.

There are certain aspects of Jacques Derrida's philosophy that can usefully be employed to unravel the etymology of R2P. ${ }^{44}$ In his essay 'Hospitality', he argues that 'it is necessary to do the impossible. If there is hospitality, the impossible must be done. ${ }^{45}$ This means that we are set 'a task to perform as a morally responsive subject ${ }^{46}$ to the Other, and are expected to offer 'something determinate' ${ }^{47}$ This requires us to contribute actively. Feeling answerable and feeling involved are thus concretised by negotiating within ourselves and being proactive in meeting our self-responsibility for the Other. Belief in the possibility of the impossible guides our decisions and actions, ${ }^{48}$ and serves as a source of responsibility. For Derrida, engagement in such decision-making and activity is entered into above and beyond the possibility of calculating consequences. They entail risk and belief in the

Kallen (1942), p 373.

Kallen (1942), p 376.

Emmanuel Levinas (1906-95) French philosopher, indebted to both Jewish dialogical philosophy and phenomenology.

Levinas (1981), p 123.

Levinas (1981), p 112.

Diprose (2004), p 8: 'A responsible democratic politics would build its selfresponsibility on responsibility for the uniqueness of others.'

Jacques Derrida (1930-2004), the leading exponent of 'deconstruction', who in later writings addressed the related issues of hospitality, justice and responsibility, and cosmopolitical right.

Derrida (2000), p 14.

Keating (2004), p 8, original emphasis.

Derrida (2003), p 129, original emphasis.

Derrida (2003), p 115. 
unrealised potential of a shared understanding of the ethos existing within communities of Others.

This kind of shared understanding has cosmopolitical (belonging to universal policy and polities) or cosmopolitan (widely diffused over the globe) contours. ${ }^{49}$ While some authors and translators use either cosmopolitical ${ }^{50}$ or cosmopolitan exclusively, ${ }^{51}$ others interchange the term. ${ }^{52}$ One of the early translators of Kant's short essay, 'The Idea of a Universal History from a Cosmopolitical Point of View' (1784), was the literary figure Thomas de Quincey (1785-1859), who renders the German term weltburgerlich as cosmopolitical. ${ }^{53}$ Interestingly, this is the term preferred by contemporary European philosophers, such as Bobbio and Derrida. ${ }^{54}$

The cosmopolitical tradition emerges from later Roman stoicism, as transmitted by Cicero and Pauline Christianity, ${ }^{55}$ and as inherited by Enlightenment figures. Stoicism has exerted a significant influence on ethical thought from early Christianity through Immanuel Kant's work. A distinctive feature of stoicism is its cosmopolitanism. The cosmopopolitical tradition is articulated in Kant's Definitive Article in View of Perpetual Peace, where the conditions of universal hospitality are also discussed. The term 'cosmopolitical' refers to a normative theory that assumes the relevant moral community is all of humanity, with state borders having no fundamental moral significance. The universal legal system represents the final phase of Kant's

49 See the Oxford English Dictionary, $2^{\text {nd }}$ edn, vol. III (1989) and Kretschmann (1939), p 245.

50 List (1827, 1909), p 99 in Chapter XI 'Political and Cosmopolitical Economy' observed that 'cosmopolitical economy ... originates in the assumption that all nations of the earth form but one society living in a perpetual state of peace'. Friedrich List (1789-1846), a German economist and sometime resident of the United States, absorbed the doctrines of the Enlightenment and of classical economics, finding in them an excellent weapon for combating the rule of an arbitrary bureaucracy and the restrictions of the lingering guild age.

51 Sutch (2001), p 57 remarks that 'the cosmopolitan perspective remains a real and important contender in international ethics'.

52 Bobbio (1996), where the translator uses the term interchangeably. Archibugi (2000), who in earlier writings (1995) used the term 'cosmopolitan', remarked that 'Contrary to previous work, I have been convinced that the term "cosmopolitical" should be preferred to "cosmopolitan", citing the reasons for change found in my The Relationship Between International Law and Democracy (University of Melbourne, 1999), unpublished ms. I use 'cosmopolitical' in Chataway (1997, 1998, 2001). Reference is also made to the constituting principles of 'cosmopolitical' in my introductions to Bobbio (2000), pp vi-xiv; see also Bobbio (2002). Norberto Bobbio (1909-2004) was a legal and political philosopher, public intellectual and foremost democratic theorist in postwar Italy. His oeuvre addresses human rights, democracy and peace, their interconnection, and the importance of the legal system (domestic and international) for human rights protection, global democratisation, and peace.

53 De Quincey (1896-97), vol IX, p 428.

54 Derrida (1994).

55 'Stoicism' available at www.britannica.com/ebc/article-68437. 
general legal system. Following the state of nature, where there is no right other than the private, there exist both the right between individuals within the State regulated by domestic public law, and the right in the international system regulated by international public law. Cosmopolitical right was conceived by Kant as the final stage of a legal process. He contends that it is not 'a representation of exalted minds', since 'with regard to the association of peoples of the earth ... the point has been progressively reached in understanding that the violation of rights which occurs somewhere on earth, is felt everywhere' ${ }^{56}$ On this Kantian premise, a cosmopolitical state will at last be constituted as the matrix within which the potential of all individuals may be fulfilled. Hence, the cosmopolitical jurisprudence underpinning an inclusive global civil society represents a realistic and rational alternative to a divided world.

In his development of the term 'cosmopolitical' for a wider context, Derrida goes beyond the old world to devise an original concept of hospitality, of the duty (devoir) of hospitality, and of the right (droit) to hospitality. ${ }^{57} \mathrm{He}$ considers urban rights to immunity and hospitality, which he contends were rigorously and juridically developed from the biblical Book of Numbers. ${ }^{58}$ Moses was commanded to establish 'six cities of refuge' or 'asylums', to assist the 'resident alien, or temporary settler'. In his latter works, Derrida contends 'that a philosopher interested in ethics and/or politics must come back to the question of the law'. 'With democracy becoming truly global, philosophers must be, can't escape, really, looking at law and justice. ${ }^{60}$ He considers Kant's 'Idea (in View) of a Universal History from a Cosmopolitical Point of View' a 'brief and difficult text', where Kant might be predicting, prefiguring and prescribing certain international institutions, which were only realized in the

56 Friedrich (1949), p 448; Kant (1795).

57 Derrida (2001), pp 16-20.

58 The Bible, 'Numbers' XXXV, 9-32. See also 1 'Chronicles' 6.42, 52 where the expression 'Cities of refuge' reappears, and Joshua 20.1-9: 'if they admit him into the city, they will grant him a place where he may live as one of themselves'.

59 Derrida (1994). See http:///A|/Derrida on cosmopolitical_files/derrida.htm. The following discussion draws on Derrida's 'cosmopolitical' views discussed therein. The roundtable discussion which followed Derrida's presentation was published in Surfaces, VI (1996). His responses to questions on 'why cosmopolitical?' are woven into this paraphrased version of his original presentation. The English version is found at file:///A|/Derrida 2 files/art derr.htm. The interview was conducted by Thomas Assheuer of Die Zeit, and at Derrida's request the full text was published in French on the Derrida website in March 1998. An abbreviated form appeared in Die Zeit on 5 March 1998, titled 'A conversation with the philosopher Jacques Derrida about intellectuals, capitalism and the laws of hospitality'. Derrida was unhappy with the printed version, and requested a caveat to the reader stating that this 'painful experiment' had led to a number of concessions and reductions to 'the simplest expression'. The original French version is found at www.hydra.umn.edu/derrida/zeit.html and the shorter in German at www.archiv.zeit.de//zeit-archiv///daten/pages/titel.txt.19980305.html. 
twentieth century, or after World War II. Among what he terms 'philosophemes' ${ }^{61}$ is the idea of international law or international rights, which those institutions attempt to implement.

In his writings, Kant perceives the whole earth as a potential global city, or a cosmopolis. He also prefigures the right of everyone to be a citizen not only of one's own state but of the whole world. According to Bobbio, 'One of the aspects of this work [Perpetual Peace, 1795] that has been studied the least is Kant's introduction of a third category of law alongside the more traditional categories of internal and external public law, which he termed jus cosmopoliticum (cosmopolitical right), ${ }^{62}$ Kant envisaged that relations between a state and its citizens would be regulated by internal public law (political right), and relations between states would be regulated by general international law (international right or ius gentium). However, he saw the need to add a tertium genus: supra-national law or cosmopolitical right. This would regulate relations between an individual state and the citizens of other states, and conversely relations between a citizen and a state other than his own. One example of this is the relation of reciprocity that entails the right of entry of a foreign citizen and the duty of hospitality by the host state. Kant, however, cautions that if one of these three laws (rights) 'lacks a principle which limits external freedom by means of laws, the structure of all the rest must inevitably be undermined, and finally collapse'. ${ }^{63}$ Moreover, upon consideration that all peoples of the earth belong to a universal community, he saw cosmopolitical right as 'a necessary complement to the unwritten code of political and international right, transforming it into a universal right of humanity' ${ }^{64}$ Based on this reasoning, the R2P norm has emerged as a contender in the evolving canon of international norms and laws. It is argued that R2P can be regarded as a particularly appropriate norm to operate in the cosmopolitical sphere, ${ }^{65}$ due to its potential to contribute to the protection of human dignity and fundamental rights of all peoples.

Derrida's notion of democracy-to-come ${ }^{6}$ reflects his interpretation of Kant's vision of humanity 'constantly progressing': 'I do not believe that the right to philosophy is dissociable from a movement of effective democratization. ${ }^{67}$ For Derrida, democracy is a promise. It is a more historical

61 'Philosophemes' are philosophical acts and archives, philosophical productions and products, not only because the concepts which legitimate them have an assignable philosophical history, but also because such institutions imply sharing a culture and philosophical language.

Bobbio (1996) where Chapter 8 discusses the distinctiveness of 'cosmopolitical right'.

63 Reiss (1970), p 137.

64 Reiss (1970), p 108, cited in Bobbio (1996), p 122.

65 Bobbio (1996), p 63. According to Kant, this sphere concerns 'the welfare of the human race as a whole, insofar as the welfare of mankind is increasing within a series of developments extending into all future ages'. 
concept of the political, and the only concept of a regime or political organisation in which history - that is, the endless process of improvement and perfectibility - is inscribed. Such a regime would be any kind of experience in which equality, justice, equity and respect for the singularity of the Other are operational. Derrida contends that we are responsible for doing 'something determinate' to produce such experiences. He maintains that the Other is already within our cosmopolitical space, and needs to be sheltered and welcomed. This also means that we have to negotiate the hospitality within ourselves, and this is a complicated unconscious operation. ${ }^{68}$ Inseparable from the thinking of justice itself, however, Derrida considers that 'unconditional hospitality remains impracticable'. He grants that 'unreserved hospitality', as he terms it, is 'an absolute pole'. The political task then is to find the best legislative arrangement, complemented by appropriate legal conditions to ensure that, in any given situation, 'the ethics of hospitality is not violated in its principle, and is respected as much as possible. To that end, one has to change laws, habits, and a whole "culture". ${ }^{69}$ Because both the concept and experience of refugees in the twentieth century have changed significantly, international politics and the legal system appear rather archaic. In order to confront the non-citizenship of people who need to be welcomed and cared for, we must devise a new democratic relationship, one that extends beyond the borders of the nation-state. ${ }^{70}$ Thus we should not confine democracy to the political realm in the classical sense, or to the nation-state, or to national citizenship. This is because globalisation has reshaped these institutions in both positive and negative forms, and hence new political practices and spaces are required to fulfil their roles. For Derrida and others who share such reasoning, the cosmopolitical space is where those new practices can address the persistent and interrelated issues of state sovereignty and the efficacy of international law. The cosmopolitical arena can also be regarded as that

68 Nussbaum (1997), p 55, footnote 39 relates the following: Kant's friend Ehregott Andreas Christoph Wasianski recounts a remarkable story about the importance hospitality for the stranger had for Kant. A week before his death, stricken in both body and mind, Kant received a visit from his doctor, a busy and eminent man. Although he could hardly speak at all, and could express his meaning only in sentence fragments, Kant struggled to express his gratitude that a man with so many obligations would take the time to call on him. When the doctor asked him to sit down, Kant did not. The doctor asked Wasianski why not, since standing was obviously giving him difficulty. Wasianski conjectured that Kant was standing out of courtesy, unwilling to sit until the stranger and guest had taken a seat first. 'The doctor seemed dubious about this reason, but he was quickly convinced of the truth of my statement and moved almost to tears when Kant, having collected his powers with main force, said, "The sense of humanity has not yet abandoned me." (Cited in Cassirer, Kant's Life and Thought (1981), pp 41213.

69 Derrida (1996).

70 This passage on defining 'democracy-to-come' draws on Derrida (1996), and Derrida (1999) found at file:///A|Derrida 1_files/derrida.htm. 
'humanitarian space' where 'every person' and their 'dignity' are placed at the centre of international politics.

Philip Allott argues that it is only through the aggregation of shared experiences, dictates of public conscience applied universally, ${ }^{72}$ responses to community revulsion and a deep sense of indignation at the atrocities detailed in visual and print media, that the 'feeling of being answerable' can be actualised. In terms of this discussion, such a process can contribute to an increased acceptance of R2P as a new international norm. Although we realise that we cannot refrain from feeling sympathy, he contends that the question of whether we feel responsibility is still of concern. ${ }^{73}$

Paul Ricoeur's work ${ }^{74}$ makes a key distinction between the juridical notion of responsibility (ex post or after the fact/event as found in Aristotle's Nicomachean Ethics) ${ }^{75}$ and the kind of responsibility that is tied to ethical identity (ex ante, or before the fact/event, illustrated by Jonas's The Imperative of Responsibility). ${ }^{76}$ There are two sides to the latter. Responsibility 'beyond the law' is theorised as a response that is determined by our limited capability and finite knowledge, but is correspondingly limitless and infinite. Ricoeur's treatment of ethical responsibility helps us to understand that responsibility is concerned with what I can do (or be held culpable for on the basis of capacity). But responsibility is also concerned with whatever or whoever is precious or vulnerable, and hence it makes a claim upon us (which sometimes quite likely exceeds our capacity). Then there is the question of the extent we may be held responsible for our incapacities so that: 'Every actual aim must be submitted to the "sieve of the norm"., 77

In effect, based on 'the feeling that we are answerable/being involved', we can be considered ethically responsible for our ignorance. This extends to the harmful consequences of our lack of global consciousness about the need to protect the most vulnerable human beings in the face of gross violations of human rights. For Ricoeur, our acceptance of such responsibility would be a way of asserting an ethical identity. This enables us to comprehend the reasons for the R2P norm. Those reasons necessarily need to emerge from a viable conception of law and ethics, which is laic, non-theological and intuitively acceptable to all humanity.

71 JG Støre, 'Old Recipes in a New World? The Challenges of Multilateralism in the 21 st Century', [Norway's Minister of Foreign Affairs], Norwegian Atlantic Committee's Annual Leangkollen Conference, Norwegian Nobel Institute, 30 January 2006.

72 The 'applied universally' notion is used by Allott (1999), p 39. More generally, see his challenging 'Dare to hope!' approach in The Health of Nations (2002).

73 Allott (2002), p 405.

74 Paul Ricoeur (1913-2005), French existentialist, theologian, philosopher, literary critic, and widely known as a proponent of phenomenological hermeneutics.

75 Aristotle (1996), The Nichomachean Ethics of Aristotle translated with notes by Harris Rackham and introduction by Stephen Watt.

76 Jonas (1984).

77 Ricoeur (1992), p 170. 


\section{R2P as an Evolving International Norm with Legal Obligations ${ }^{78}$}

In both international relations and general international law, there is a considerable body of literature on norms, norm formation, and the incremental development of normative consensus. Data reveal that to date normative progress of the R2P concept is evident, but widespread acceptance has been constrained by the increased complexity of international politics following 9/11 and the wars in Afghanistan and Iraq, and by its dependency on the power of persuasion of international law.

Norms are distinguishable from, yet linked to, principles, rules and decision-making procedures. The efficacy of norms rests on their intersubjectiveness - that is, they have linkages and interconnections with a multitude of individuals and multilateral institutions. Those interactions constitute a patterning of human behavioural and social processes, which are essential to social cohesion within and between liberal societies. Norms are constitutive since they define particular characteristics as, for example, the rule of law being fundamental to a good working democracy. They are also regulative because they stipulate conditions under which individuals, states and institutions behave. Arguably, given the substance of paragraphs 138 and 139, and Security Council Resolutions 1674 and 1706, the emerging R2P norm represents the logical consequence of an increasing global consensus on the need for a new rule of customary international law that can effectively protect human dignity and basic rights.

Five typical stages in the life cycle of norms are outlined below. ${ }^{79}$ Based on the above historical data, the R2P norm is evolving according to this life cycle,${ }^{80}$ and the final two stages are most pertinent.

\section{Stage 1: Conception}

First, the norm's definition should be clear and unambiguous, with its intersubjective characteristics evident and recognised. Championing by one or more committed advocates who understand formal and informal processes of gaining acceptance, the importance of dialogue, agenda-setting, coalitionbuilding, cultural and institutional differences, the emotion of language, and borderless relationships at an international level will provide essential public exposure. The R2P report and its championing by the co-chairs through keynote addresses, conference papers, and academic articles in international

78 On this topic, see WA Knight, 'The Responsibility to Protect as an Evolving International Norm', Notes for Canadian Peacebuilding Coordinating Committee Meeting, Ottawa, 22 September 2003. For a conceptual framework on norm development see Norms and The Responsibility to Protect Meeting Report, Canadian Conference Centre, Ottawa, 7 April 2003.

79 For understanding of norm evolution from a life cycle perspective, see Finnemore (1996); Risse et al (1999); Stromseth (2003).

80 A most useful attempt to analyse the evolution of the R2P norm can be found in KP Coleman, "A Place to Stand": Institutional Settings for International Norm Change', paper prepared for the 2004 Annual Meeting of the American Political Science Association, 2-5 September 2004. 
journals and the media highlighted the R2P norm's potential. Its conpenetration, supported by then Secretary-General Kofi Annan, suggests that the conception stage is sufficiently, but not universally, established. The debates on R2P in the General Assembly during 2004 and 2005 reflect this reality. ${ }^{81}$

\section{Stage 2: Diffusion/cascading}

Norm champions and like-minded actors play a critical role in persuading the multi-layered international community (individuals, civil society, states and international institutions) of the need in current situations of conflict for a norm such as R2P. Global civil society can assert its strength through its involvement. One commentator highlights the need to encourage engagement at the people's level, because 'in practice, this participation still belongs primarily to an exclusive club: members of the English-speaking, universityeducated, Internet-connected, plane-riding global elite will find it much easier to participate than others'. ${ }^{82}$ The mass of state practice, numerous conferences, seminars, plenary sessions, academic and commissioned research, and engagement by global civil society organisations in long-term research demonstrate that the diffusion stage is well underway.

\section{Stage 3: Embeddedness}

A norm must be sufficiently robust to be inner- and outer-directed, and conformed to in a routinised and non-reflective manner. Before the $2005 \mathrm{UN}$ Summit, this stage predominated in the evolution of R2P. "Norm entrepreneurs' such as Gareth Evans and William Pace of the World Federalist Movement contributed significantly to this process. A relevant paper was placed before the High-level Panel, whose report was officially handed to Secretary-General Kofi Annan on 2 December 2004. The Association of the Bar of the City of New York held the first public discussion of the contents of that report on the same day. The embeddedness stage is slow. Recently Security Council Resolutions 1674 and 1706 contributed to R2P's progression from a paper rule, and are promoting it as a working rule in Darfur. Yet a deal more remains to be done. There are some definitional difficulties concerning the term that can hinder evolution. Evans and Slaughter's debate at the ASIL 2004 conference as to whether responsibility to protect should be termed 'duty to prevent' epitomises such terminological differences. ${ }^{83}$ Scepticism may have implications for the norm's embeddedness: "Why will changing the buzz words ... from "right to intervene" to "responsibility to protect" have any effect on humanity's underlying divisions? ... [I]t may have the opposite effect ... and could well found a new basis for debate about whether these highly

81 See 59th and 60th General Assembly Plenary Sessions at www.un.org.

82 Glasius (2003).

83 See Feinstein and Slaughter (2004); Evans (2004). 
malleable and elastic precepts have been complied with. Humanity's disagreements ... are about substance, not language. ${ }^{84}$

\section{Stage 4: Contestation}

Contestation occurs both internally and externally, as this process involves relations with state practice and customary international law. ${ }^{85}$ A statement by Secretary-General Kofi Annan during the 1999 Kosovo crisis that a norm of humanitarian intervention was emerging illustrates such contestation over humanitarian intervention ${ }^{86} \mathrm{He}$ congratulated the ICISS for its report and, with regard to the R2P recommendation, remarked: 'I wish I had thought of the term. It would have saved me a lot of effort, anguish, and time.' He was, of course, referring to the mixed response in the General Assembly to his 1999 address, and his 'Two Concepts of Sovereignty', and the ensuing debates. Another example of the emerging R2P norm challenging the non-intervention norm is the United States-led coalition-of-the-willing invasion of Iraq without Security Council approval. Four years on, the loss of innocent civilian life, the atrocities committed against Iraqi prisoners, the devastation and social deterioration caused by ethnic insurgency, and the lack of a realistic exit strategy are reasons for widespread global concern about both the 'humanitarian' and 'intervention' aspects of the invasion. It is worth noting that the conjoined term 'humanitarian intervention' did not appear in $A$ More Secure World. In its place, and employed once only, at paragraph 12 , is the term 'intervention for humanitarian reasons'. At paragraph 158, there are comments on the need 'to live up to basic humanitarian principles'. The preferred term used to encompass and underpin the international community's action towards 'collective security' is either R2P or 'shared responsibility', which, however, conveys a different meaning to the term 'collective security' employed in the UN Charter 60 years ago.

\section{Stage 5: Dissolution}

During this stage, an internal inconsistency emerges in an existing norm; this is challenged by an emerging norm, and the former either adjusts into a new form, or becomes weaker and succumbs. The wars of the 1990s, the aftermath of $9 / 11$ followed by the 2003 Iraq invasion, and the international outrage at the gross violations of human dignity during the Darfur crisis, demonstrate the urgent need for the international community to exercise a shared responsibility towards the victims and most vulnerable people in any state where the state cannot or will not provide protection or even the basic means for survival. This dissolution stage challenges the legal-political nexus inherent in such circumstances because it informs diverse agenda-setting techniques, and how

84 Glennon (2006), pp 312-13, slightly rephrased without altering the intent of the passage.

85 Pauwelyn (2003).

86 Relevant humanitarian intervention material prior to the emergence of R2P is found in Abiew (1999); Lepard (2002); Holzgrefe and Keohane (2003); and Finnemore (2004). 
international political will is managed. To illustrate, John Danforth, then US Ambassador to the UN, became exasperated when a move by South Africa effectively blocked the vote on the proposed Darfur measures in the General Assembly's committee on social, humanitarian and cultural affairs. In a passionate outburst, he claimed that the General Assembly was condoning inaction, atrocities and the status quo in that situation. ${ }^{87}$ Danforth resigned on 22 November $2004 .^{88}$

At another level, the controversies over the extent of normative consensus that $\mathrm{R} 2 \mathrm{P}$ has so far attained might also be regarded as an aspect of the broader debate on the fragmentation of international law. ${ }^{89}$ In practice, the acceptance and operationalisation of a new norm are a challenge to international law as a system. This, however, allows for overlap between self-contained international law regimes so far devised to protect human dignity and fundamental rights. Here it is contended that the R2P norm can better accommodate, or perhaps be more responsive to, the theorisation of human dignity. ${ }^{90}$ More time is needed for the process of recognition and general acceptance of this norm to be completed. Or at least a practice of sufficient density, in terms of uniformity, extent and representativeness, must accumulate for R2P to ultimately become a rule of customary international law. ${ }^{91}$

\section{The Crucial Role of Civil Society Organizations (CSOs)}

CSOs derive from three institutional bases: formal organisations that link national institutions (such as the World Council of Churches, the ASEAN Peoples Association, and Project Ploughshares); linkages between informal networks and movements (such as women's, gay and peace groups); and globalist organisations (such as Amnesty International, Citizens for Global Solutions, Greenpeace, Médecins sans Frontières, One World Trust, World Federalist Movement), all of which are established with a specifically global orientation.

The role of CSOs in the life-cycle of the R2P norm, particularly during diffusion, embeddedness and contestation, cannot be under-estimated. Generally, CSOs contribute in many important ways to consensus-building and state practice. State practice and opinio juris sive necessitatis are the

87 USUN Press Release \#262 (04) 23 November 2004: 'The message from the General Assembly is very simple. You may be suffering, but we can't be bothered'.

'Diplomats at UN Surprised by Danforth's Resignation', The New York Times, 3 December 2004.

$89 \quad$ Koskenniemi and Leino (2002), p 553.

90 Human dignity is the inalienable right to be treated with a basic level of respect, which 'provides the causa, as well as the ratio, for all human rights legislation': Cohn (1983), pp 231-32, original emphasis.

91 International Law Association, Final Report of the Committee on the Formation of Customary (General) International Law, Statement of Principles Applicable to the Formation of General Customary International Law, Report of the Sixty-Ninth Conference, (2000), Principle 4 and commentary thereto. 
constitutive objective and subjective elements respectively of customary international law. State practice consists of the various activities by states, which include treaty ratifications, public statements and declarations. Opinio juris relates to the conviction by states that such practice is required by law. It is this element that distinguishes legal custom from mere habit, social practice or public policy. Hence the strength of customary international law rests on a set of shared understandings, or collective knowledge, which can generate political will within states and internationally. International political will is more than the aggregation of the attitudes and policies of individual countries. A critical dimension of it is the cooperation between states and other international actors which can contribute to policy decisions, and which will determine the extent and modality of humanitarian and/or military intervention when crises or conflicts emerge. It must be remembered, however, that while the contribution by CSOs is vital, 'foreign-policy decision making processes define and influence the limits circumscribing potential humanitarian interventions, ${ }^{92}$

Non-governmental organisations (NGOs) operate in three or more countries, and are funded by more than one country. A dense network that connects such organisations globally is now well established. As a result, the number of international non-governmental organisations (INGOs), such as Save the Children, Amnesty International, Oxfam, Médecins sans Frontières, and the International Federation of Red Cross and Red Crescent Societies, has increased. The resultant civil society dialogue has highlighted areas of analysis with a broad and growing support base among people of quite diverse backgrounds. Overall, these three groupings (CSOs, NGOs and INGOs) strive to raise public awareness of many contentious issues, generally in a constructive manner. They educate communities about good governance, and assist in maintaining some stability wherever civil society may be weak or absent. They are an important resource in terms of advocacy and implementation, and provide a platform for continuous debate and action. Above all, CSOs share a deep concern for the future of the globe and its inhabitants. Such concern can be encapsulated by 'the feeling of being answerable'. The various activities undertaken by CSOs motivate people to active democratic participation in public policy debates. As a result, citizens are reasserting their individual sovereignty, and demonstrating that they are no longer willing to leave issues solely to mainstream political parties and special interest lobbyists. Many individuals are exercising their right to reshape their communities in ways that better respond to their present needs and future aspirations. Thus, individual sovereignty and state sovereignty can work together. The R2P report reframed the state sovereignty/non-intervention question, reinvigorated global debate and renewed public confidence in CSOs.

Our global mix comprises the collective concern of CSOs for human dignity and individual sovereignty, ideological and religious differences that encompass Western and other belief and value systems, and the exercise of hegemonic power by the one remaining super-state. The UN $60^{\text {th }}$ anniversary

92

ICISS (2001), p 208. 
meeting (2005) faced remarkably different global conditions from those of 1945. Yet we remain leg-roped to conventional and traditional practices, without giving fuller recognition to the development of global telecommunications technology that has truly made us 'one world'. To unravel the current agenda and manage such a complex process, the world needs the UN as 'a third party super partes' ${ }^{93}$ This is notwithstanding the fact that it must be appropriately reformed at least along the lines contained in $A$ More Secure World. However, with the clear exception of the formal recognition of the R2P principles, the outcomes of the UN 2005 were disappointing. Subsequently, most opinion statements emphasise that the 'commitments on paper must be realised in action'. ${ }^{94}$ That is, paragraphs 138 and 139 need to be 'translated from rhetoric into action, ${ }^{95}$ Largely, all the statements concurred with the view that CSOs should hold their governments accountable, and continue their advocacy for the implementation of the emergent R2P norm at national, regional and international levels.

\section{R2P and the Darfur Hecatomb}

Darfur is a highly complex political and social context, and is often referred to as a 'human-made' disaster. ${ }^{96}$ It is the epicentre of three overlapping circles of an internal armed conflict. First, a war commenced between the Sudanese government in Khartoum and two armed resistance groups, the Sudanese Liberation Army (SLA) and the Justice and Equality Movement (JEM). Second, there was a proxy war between Sudan and Chad, with each country hosting and supporting the other's rebel groups. Third, localised conflicts are primarily based on land tensions between sedentary and nomadic tribes. ${ }^{97}$ This conflict originally began in August 2002, when Sudan deployed its armed forces to try to control the insurgency. The operation extended until February 2003 but was unsuccessful. In April 2003, the rebel forces attacked the airport at Al Fashir (North Darfur), inflicting heavy losses on the government. Subsequently, the government ceased peace negotiations with the rebels, recruited a large number of militia (Janjaweed) and embarked on a full-scale counter-insurgency operation or so-termed 'scorched-earth campaign' that also resulted in 'cultural genocide'. Of a population of six million, more than 1.5 million persons were displaced; in excess of 200,000 crossed the border into the remote, barren regions of Eastern Chad. Thousands saw their families

93 Chataway (2001), p 136.

94 See CEBO Council of Ethics-Based Organizations Associated with the Department of Public Information of the United Nations, 14 September 2005, citing William Pace, Executive Director of the World Federalist MovementInstitute for Global Policy.

95 See DFID's Humanitarian Policy, Saving Lives, Relieving Suffering, Protecting Dignity, Conflict, Humanitarian and Security Department, 17 January 2006 (Draft).

96 P Verney, 'Darfur's “Human-made” Disaster', Green Left Weekly, 28 July 2004.

97 This depiction is taken from International Crisis Group Africa Report No. 125, Darfur: Revitalising the Peace Process, 30 April 2007. 
killed, abducted, abused or raped. Estimates vary, but over 50,000 died. Incursions by the Janjaweed on Darfur's black African tribes have been regarded as genocide. But 'the international community ignored Darfur for too long, letting it rage out of control' ${ }^{98}$ Only belatedly did the conflict attract international attention. Both the Security Council and General Assembly have been criticised for their position of condoning inaction.

To date, conditions for the displaced Darfurians remain appalling. Lack of food and incessant rains drastically increased the threat of water-borne diseases. Many roads became impassable, and aid distribution was severely hindered. Many relief workers were murdered. In certain areas, air lifts of food and medical supplies were the only means of support. Relief organisations such as Oxfam joined many communities to assist in the struggle against the spread of disease and improve the minimal conditions of survival. In July and August 2003, Sudan's armed forces together with the Janjaweed attacked the towns of Kodoom, Bindisi and Mukjar. Shortly afterwards, the government and the rebel groups signed a peace agreement in Abeche. However, the rebels continued, and increased, their attacks against the government. The armed forces and Janjaweed resumed military operations, and in December 2003 attacked Arawala (West Darfur). The government blocked the main crossings into Chad, stopped its attacks in West Darfur and in January 2004 concluded all major military operations. After losing control of North and West Darfur, the rebels shifted their action to the South. Sudanese Armed Forces attacked a rebel base in the Sindu Hills, causing residents to flee to Mukjar. The town was subsequently attacked by both the armed forces and Janjaweed. They allegedly killed or tortured dozens of civilians, destroyed private and public property, and pillaged livestock, crops and goods.

The African Union acted as a mediator, and troops from Nigeria and Rwanda were sent to Sudan as members of an African Union peacekeeping force. In April 2004, the government and the rebels signed a ceasefire agreement. However, the rebels continued their attacks in South Darfur, prompting the government to engage in another military operation in December 2004. With the distinct possibility of peace talks breaking down, the United States pressured the Security Council and General Assembly to provide a greater lead to a settlement outline. On 18 September 2004, Security Council Resolution 1564 alleviated the suffering of the Darfurians, particularly through the assistance and document verification provided by African Union personnel. However, that document lacked substance, except for the recommendation that the Secretary-General be authorised to 'rapidly establish an international commission of inquiry to investigate reports of violations of international humanitarian law and human rights law in Darfur, and whether acts of genocide have occurred, ${ }^{99}$

The threat of sanctions remained if Sudan did not observe this Resolution, or failed to cooperate with the African Union Monitoring Mission in Darfur.

99 Available at www.un.org/Docs/sc/unsc_resolutions04.html, on 'Report of the Secretary-General on the Sudan'. 
No mention was made of humanitarian intervention principles. Rather, this Resolution reaffirmed the UN's commitment to the sovereignty, unity, territorial integrity and independence of Sudan. Khartoum argued that the more outside pressure was applied on it at this sensitive time, the more likely it was to be counterproductive. The wording of the Resolution may suggest that Khartoum's argument was attractive to states, and this in part explains the Security Council's cautious action and world leaders' ambivalence. ${ }^{100}$

Excerpts from Security Council Members' Statements on Security Council Resolution 1564 relating to R2P and Darfur are relevant: 'the situation is totally unacceptable as regards the renewed commitment of the UN in favour of human dignity'; 'there is a need for further and unequivocal actions by the Government of Sudan in carrying out its primary responsibility to extend protection and security to the civilian population'; 'A State has the responsibility to protect its citizens, and, if it is unable or unwilling to do so, the international community - the Security Council - has the moral and legal authority to enable that State to assume that responsibility'; 'there should be no moral hesitation in the Council in taking up its responsibilities'; 'The Security Council cannot neglect its responsibilities'; 'the pressure of the international community has been chiefly responsible for this progress'; 'to protect the people of Darfur, who have been suffering terribly and in a way that is unique in the tragedies of the world today'. ${ }^{101}$ A terminology shift has occurred here, with an increased use of the terms 'responsibility' and 'protect' and 'pressure from the international community'. Arguably the statements accord with the definition of state practice in the diffusion stage of the lifecycle of the R2P norm.

However, placing human dignity at the centre of the UN's agenda remains a slow, deliberative process. This could well be expedited as the potential utility of the emerging norm becomes more globally understood, and gains widespread acceptance by the international community. Currently, significant pressure from civil society on some of the major states to exercise their obligation is mounting. Additionally, with Security Council Resolution 1706, the concerted efforts of the World Federalist Movement, Global Policy Forum and Africa Action, the considerable recent literature developed by Evans ${ }^{102}$ and academic commentators, ${ }^{103}$ the renewed sense of legal obligation necessary to implement the R2P norm is strengthening.

100 International Crisis Group (ICG) Africa Briefing, 5 October 2004, citing an interview by the Cincinnati Enquirer editorial board, 16 August 2004. The then US Secretary of State Colin Powell commented: 'Khartoum certainly has to do a lot more. It's a very difficult thing to calibrate and I have to deal with this every day. How much pressure can you apply without the pressure starting to become counterproductive because the regime in Khartoum says, "Okay. We're not going to do anymore. Darfur is all yours. No[w], you do it." Or do you just keep applying pressure to make them respond?'

101 Security Council meeting record S/PV.5040.

102 For instance, refer to the International Crisis Group 15-page primer on R2P at www.crisisgroup.org.home/index, which traces the evolution of the concept, lists Evans' speeches, and provides an informative bibliography to the end of 2006 on 
The newly appointed UN Secretary-General Ban Ki-moon visited Sudan, and stated he had established a position of trust with Sudan's President Bashir. The Secretary-General anticipated his support in the current negotiation process to establish the combined African Union-UN hybrid protection force. ${ }^{104}$ In his report to the Security Council on Sudan, ${ }^{105}$ he contends that the paramount goal for international complementary efforts in the areas of security, political and humanitarian assistance must be to stabilize Darfur sufficiently so that its residents are able to participate in the 2009 midterm elections along with the rest of the country'. ${ }^{106}$

On a positive note, in April 2007 Sudan announced it would allow 3,000 international peacekeepers into Darfur. Some observers contend that Sudan's decision reflects China's increased influence on Khartoum to respond to growing pressures from the international community. The threat of UN sanctions may also have contributed. In addition, there are the arrest warrants issued by the ICC (2 May 2007) for Sudan's Humanitarian Affairs Minister Ahmad Arun and the Janjaweed 'colonel of colonels' Ali Kushayb, who allegedly are 'criminally responsible' for war crimes and crimes against humanity. These warrants list 51 counts for each accused, which include persecution, murder and attacks against civilians, forcible transfer, rape, pillaging, destruction of property, inhumane acts, imprisonment and torture.

The persistence and intractability of this harsh conflict has generated developments which continue to impact on vulnerable civilians. Various initiatives to stabilise the country, and build an effective peace process, have failed. Despite the numerous appeals for urgent action, there is yet no coordinated effort by all the relevant parties to address first and foremost the protection of civilians, or related issues such as power-sharing, wealth, individual compensation and disarmament of the Janjaweed militia, or complex questions concerned with justice. The latter include questions about punitive measures and sanctions for the perpetrators of human rights violations. The current position is that "with the right policies and increased levels of engagement on the issue, there is potential for Darfur to stabilize within a year. If not, it is almost a foregone conclusion that hundreds of thousands more will be killed on our watch in 2007., 107

On the ground, the protagonists are facing the enforcement of Security Council Resolutions 1674 and 1706. Recent international law developments

R2P generated since the ICISS Report of December 2001. This present article refers to early 2007 titles and events, particularly in relation to progress in Darfur against the R2P background and SC Res 1706.

103 Breau (2006).

$104 \mathrm{http}: / /$ news.bbc.co.uk/2/hi/africa/6319359.stm.

105 UN Security Council S/2007/213 Report of the Secretary-General on the Sudan, 17 April 2007.

106 UN Security Council S/2007/213 Report of the Secretary-General on the Sudan, 17 April 2007, para 87.

107 J Prendergast of the International Crisis Group cited in 'The Answer to Darfur', Strategy Paper 1, March 2007, www.enoughproject.org. 
are relevant to Darfur. The ruling by the International Court of Justice (ICJ) in the Bosnia v Serbia case states that, in principle, states can be held responsible for genocide. ${ }^{108}$ The ICJ ruling reaffirms the important distinction between ethnic cleansing and the ultimate crime, genocide. The finding that Serbia failed to prevent and to punish genocide is quite significant because it is the first time in history that an international court has judged a state legally responsible for violating the Genocide Convention. The potential remains for Sudan to be judged responsible for genocide, notwithstanding that such responsibility is extremely difficult to prove as intentional performance by a specific state.

The International Law Commission 2001 Articles on State Responsibility (particularly Articles 40,41 and 16) have the potential to place the Sudanese government in an invidious legal-political position. Sudan must also confront customary international humanitarian law Rule 55, according to which: 'The parties to the conflict must allow and facilitate rapid and unimpeded passage of humanitarian relief for civilians in need, which is impartial in character and conducted without any adverse distinction, subject to their right of control. 109 It is encouraging to note that there are some clear signs of acceptance of the emerging norm of R2P across all levels of society. However, its operationalisation still depends largely on the international community grasping the opportunity to redress its failed obligation towards the people of Darfur. Currently, Rule 55 is being blatantly ignored in Darfur. The application of legal-political pressure is becoming incontrovertible through Security Council Resolutions 1674 and 1706. This is a crucial step towards bringing atrocities in the Sudanese province to international justice. ${ }^{10}$

\section{Conclusion}

To restore and/or extend justice and the rule of law throughout the world will depend on the hold law has on our consciences, ${ }^{111}$ and how our international mind reacts to the rapid transformations in political and social relations. The ripening of R2P as a norm can be a significant advancement in the evolution of sovereignty as responsibility, or obligation, of states to protect vulnerable populations. The operationalisation of R2P in a context that 'rigorously upholds international law and fulfils our responsibility to protect innocent civilians from genocide, crimes against humanity and war crimes' ${ }^{\prime / 2}$ requires further action in the following four significant determinative areas:

108 Application of the Convention on the Prevention and Punishment of the Crime of Genocide (Bosnia and Herzegovina $v$. Serbia and Montenegro) - Judgment of 26 February 2007. See press release 2007/08, Summary and full text of the Judgment at www.icj-cij.org.

109 Henckaerts and Doswald-Beck (2005).

110 'ICC Issues First Darfur Arrest Warrants', Telegraph(UK), 3 May 2007.

111 Secretary-General's address to the General Assembly, New York, 21 September 2004.

112 Secretary-General's address to the General Assembly, New York, 21 September 2004. 
- a broader dissemination of the R2P concept at both the civil and institutional levels, nationally and globally;

- greater consideration at diplomatic levels of this increased acceptance of the R2P concept by global civil society;

- increased recognition by the Security Council of the contribution of CSOs to the evolution of $\mathrm{R} 2 \mathrm{P}$ as a norm, and its crystallisation leading to jus cogens and customary international law. This is based on the understanding that responding to widespread human suffering should not be perceived by states as a threat to their sovereign rights;

- evaluation of the different responses to paragraphs 138-39, and to Security Council Resolutions 1674 and 1706, particularly with reference to the acceptance of the emerging R2P norm. In A More Secure World, both 'responsibility to protect' and 'our shared responsibility' are considered essential principles to attain a more secure world.

During 2002, despite preoccupations with terrorism and the threat of (presumed) weapons of mass destruction after $9 / 11$, dissemination of R2P principles gradually gained attention in academic and political debates. Subsequently, arguments over the 2003 United States-led invasion of Iraq and the continuing war marginalised that process. ${ }^{113}$ With the release of A More Secure World, the momentum increased, and was demonstrated by paragraphs 138-39. Currently, the necessary conditions exist for a new norm to emerge out of the contestation stage. But whether they are sufficient, only time will tell. While the increased thrust by CSOs is apparent, the critical question that remains is whether their commitment will be complemented by the political will of the majority of member states.

Only through a holistic cooperative approach can protection from the scourge of conflict and mass violence against vulnerable people be achievable. As international democratisation extends throughout our cosmopolitical world, perhaps one of the better arguments for democracy may be that "it insists on an "ethics of responsibility" to be generalized'. 114 R2P is a promise yet to be realised, integral to customary international law, and consistent with a democracy-to-come. To paraphrase Kant, we must consider it a legal and moral imperative, and our 'duty' to work incessantly for it. ${ }^{115}$

Rather than exhortations 'to do something', the call is for 'some good solid analysis and creative new ideas about what realistically can be done what are the underlying issues, who has the leverage, what coalitions can be mobilised: generally, who can do what, when, where and how'. ${ }^{116}$ Such an ex ante approach to arguments is consistent with an acceptance of Kallen's 'youness', Levinas's 'responsibility for the Other' and the 'negotiating within ourselves', Jonas's 'imperative of responsibility', Derrida's 'something determinate' and Ricoeur's 'sieve of the norm'.

\footnotetext{
113 Evans (2003), p 70.

114 Koskenniemi (2004), p 851.

115 Kant (1887), p 230.

116 Such as by Evans (2006), available at www.crisisgroup.org/home/index.
} 
Evans acknowledges the conceptual breakthrough with Security Council Resolutions 1674 and 1706, and the formal embrace by the international community of the R2P concept. However, he highlights the following aspects of unfinished business:

- the need to persuade the Security Council to provide specific guidelines for the legitimate use of military force, at least in the context of R2P;

- the problem of capacity requiring that, if we are to exercise R2P particularly to react to clear and present dangers - the essential civilian and military resources are always available in the right amounts;

- the recurrent problem of generating the international political will to act.

In his view: 'Our common humanity demands that the responsibility to protect be a permanent item on the global security agenda - as a matter not just of principle but of operational practice. ${ }^{117}$ Since R2P encompasses much more than national self-interest and obligation, it supersedes humanitarian intervention reasoning. Moreover, R2P ought to be regarded as a function of our common humanity that enables us to safeguard our human heritage. This implies respect for the human dignity of everyone. It is acknowledged that these are not new considerations. Yet with the movement toward cosmopolitical democracy, a heightened global awareness provoked by a more active international mind and enjoined by a universal sense of feeling answerable, the international community can no longer ignore the persistent cries of pain and distress of scores of human beings across the globe. The Darfur hecatomb is becoming a litmus test for R2P. Whether R2P will become operational with sufficient frequency to be considered a working rule rather than a paper rule remains to be seen. Significantly, we should not regard R2P as a secluded island but rather as an intrinsic part of international law territory. ${ }^{118}$

R2P is integral to the affirmation of a culture of accountability and the dictates of public conscience. Their impact on international law as process ${ }^{119}$ has in part become evident through the judgments from the ad hoc International Tribunals. The emanating jurisprudence is gradually being incorporated in international humanitarian law, ${ }^{120}$ and this in turn will influence customary international law. But it will take time. Ultimately, however, international political will is the crucial element that will facilitate the maturation of the emerging R2P norm into a rule of customary international law to be upheld by the majority of states, so that collective security can become the primary fulcrum for human dignity protection.

117 Available at www.crisisgroup.org/home/index.

118 The 'island' metaphor comes from Pauwelyn (2003), p xi, and is more fully developed in his article for a symposium (2004).

119 In the sense in which Higgins (1994) uses the term.

120 Refer Prosecutor v Kupreskic et al, JL/P.I.S./462-E, 14 January 2000, paras 527 and 537. 


\section{References}

Francis Kofi Abiew (1999) The Evolution of the Doctrine and Practice of Humanitarian Intervention, Kluwer.

Philip Allott (1999) 'The Concept of International Law' 10 European Journal of International Law 31.

Philip Allott (2002) The Health of Nations. Society and Law Beyond the State, Cambridge University Press.

Kofi Annan (1999) 'Two Concepts of Sovereignty' The Economist, 18 September.

Daniele Archibugi (2000) 'Cosmopolitical Democracy' 4 New Left Review 137.

Daniele Archibugi and David Held (1995) Cosmopolitan Democracy: An Agenda for a New World Order, Polity Press.

Aristotle (1996) The Nicomachean Ethics of Aristotle, trs. with notes by Harris Rackham and an introduction by Stephen Watt Ware, Wordsworth.

Kemal Baslar (1998) The Concept of the Common Heritage of Mankind in International Law, Martinus Nijhoff.

Frédéric Bastiat (c 1996 [1849]) Economic Harmonies, Foundation for Economic Education. Isaiah Berlin (1998) 'My Intellectual Path' XLV New York Review of Books 60.

Norberto Bobbio (1996) The Age of Rights, Polity Press.

Susan C Breau (2006) 'The Impact of the Responsibility to Protect on Peacekeeping' 11 Journal of Conflict \& Security Law 429.

Teresa Chataway (1997) 'Norberto Bobbio and the Two Republics: The Responsible Citizen' 3 Convivio 133.

Teresa Chataway (1998) 'Norberto Bobbio and the Two Republics: II The Republic for All Citizens' 4 Convivio 45.

Teresa Chataway (1999) 'The Relationship Between International Law and Democracy' University of Melbourne, unpublished ms.

Teresa Chataway (2000) 'Translator's Preface', in Norberto Bobbio, In Praise of Meekness, Polity Press.

Teresa Chataway (2001) 'Where Does the Dove of Peace Fly?' 7 Convivio 136.

Teresa Chataway (2002) 'Introduction' to Norberto Bobbio, A Political Life, Polity Press.

Haim Cohn (1983) 'On the Meaning of Human Dignity' 13 Israel Yearbook on Human Rights, Israel Yearbook Publications.

Thomas De Quincey (1896-97) The Collected Writings of Thomas De Quincey, Vol. IX, D Masson ed, Black.

Jacques Derrida (1994) 'The Right to Philosophy from a Cosmopolitical Point of View' IV Surfaces np.

Jacques Derrida (1998) 'An Interview with Jacques Derrida' Cardozo Life Fall, np.

Jacques Derrida (1999) 'Politics and Friendship. A Discussion with Jacques Derrida' at the Centre for Modern French Thought University of Sussex, 1 December.

Jacques Derrida (2000) 'Hospitality', B Stocker and F Morlock trans, 5 Angelaki 3.

Jacques Derrida (2001) On Cosmopolitanism and Forgiveness, Routledge.

Jacques Derrida (2003) 'Autoimmunity: Real and Symbolic Suicides', in G Borradori (ed), Philosophy in a Time of Terror: Dialogues with Jürgen Habermas and Jacques Derrida, Chicago University Press.

Rosalyn Diprose (2004) 'Responsibility in a Place and Time of Terror' 3 borderlands $e$ journal.

Gareth Evans (2003) 'When is it Right to Fight?' 46 Survival 70. 
Arthur Eyffinger and PH Kooijmans (1999) The 1899 Hague Peace Conference, Martinus Nijhoff.

Lee Feinstein and Anne-Marie Slaughter (2004) 'The Duty to Prevent', Foreign Affairs $\mathrm{Jan} / \mathrm{Feb}$

Martha Finnemore (1992) National Interest in International Society, Cornell University Press.

Martha Finnemore (2004) The Purpose of Intervention: Changing Beliefs about the Use of Force, Cornell University Press.

Carl Joachim Friedrich (ed) (1949) The Philosophy of Kant: Immanuel Kant's Moral and Political Writings, Modern Library.

Marlies Glasius (2003) 'How Activists Shaped the Court' The Magazine, Crimes of War Project.

Michael J Glennon (2006) 'The Emerging Use-of-Force Paradigm' 11 Journal of Conflict $\mathcal{E}$ Security Law 309.

Jurgen Habermas (1996) Between Facts and Norms, MIT Press.

Jean-Marie Henckaerts and Louise Doswald-Beck (eds) (2005) ICRC Customary International Humanitarian Law, Cambridge University Press

JL Holzgrefe and Robert $O$ Keohane (eds) (2003) Humanitarian Intervention: Ethical, Legal, and Political Dilemmas, Cambridge University Press.

Rosalyn Higgins (1994) Problems and Process, Clarendon Press.

Aaron Jonah Jacobs (1917) Neutrality versus Justice, TF Unwin.

Hans Jonas (1984) The Imperative of Responsibility: In Search of an Ethics for the Technological Age, Chicago University Press.

Horace M Kallen (1942) 'Responsibility' 52 Ethics 363.

Horace M Kallen (1948) The Liberal Spirit. Essays on Problems of Freedom in the Modern World, Cornell University Press.

Immanuel Kant (1939[1795]) Perpetual Peace: A Philosophical Sketch, NM Butler trans, Columbia University Press.

Immanuel Kant (1887) The Philosophy of Law, W Hastie trans, T \& T Clark.

Paula Keating (2004) 'The Conditioning of the Unconditioned: Derrida and Kant' 3 borderlands e-journal 1.

Martti Koskenniemi (2004) "'By Their Acts You Shall Know Them" (and Not by Their Legal Theories)' 15 European Journal of International Law 851.

Martti Koskenniemi and Päivi Leino (2002) 'Fragmentation of International Law? Postmodern Anxieties' 15 Leiden Journal of International Law 553.

Phillip Kretschmann (1939) 'An Exposition of Kant's Philosophy of Law', in GT Whitney and DF Bowers (eds), The Heritage of Kant, Princeton University Press

Brian D Lepard (2002) Rethinking Humanitarian Intervention, Pennsylvania State University Press.

Emmanuel Levinas (1981) Otherwise than Being or Beyond Essence, Kluwer.

Friedrich List (1827) 'Political Economy is Not Cosmopolitical Economy' Philadelphia National Gazette, 27 November.

Friedrich List (1904) The National System of Political Economy, S Lloyd Sampson trans, Longman Green and Co.

Theodor Meron (2000) 'The Martens Clause: Principles of Humanity, and Dictates of Public Conscience' 94 The American Journal of International Law 79. 
Catherine Mills and Fiona Jenkins (2004) 'Unassumable Responsibility: New Perspectives on Freedom, Justice and Obligation' 3 borderlands e-journal 5.

Shigeki Miyazaki (1984) 'The Martens Clause and International Humanitarian Law', in Studies in Honor of J Pictet Martinus Nijhoff, Comité international de la Croix-Rouge.

Michael O'Hanlon and Peter Singer (2004) 'The Humanitarian Transformation: Expanding Global Intervention Capacity' 46 Survival 1.

Martha Nussbaum (1997) 'Kant and Cosmopolitanism', in J Bohman and M LutzBachmann (eds), Perpetual Peace: Essays on Kant's Cosmopolitan Ideal, MIT Press.

Joost Pauwelyn (2003) Conflict of Norms in Public International Law, Cambridge University Press.

Joost Pauwelyn (2004) 'Bridging Fragmentation and Unity: International Law as a Universe of Inter-connected Islands' 25 Michigan Journal of International Law 903.

Vladimir Pustogarov (1999) 'The Martens Clause in International Law' 1 Journal of the History of International Law 125.

Vladimir Pustogarov (2000) Our Martens: FF Martens International Lawyer and Architect of Peace, Kluwer.

Gustav Radbruch (1936) 'Justice and Equity in International Relations' in N Bentwich et al, Justice and Equity in the International Sphere, Constable \& Co.

P Sreenivasa Rao (1975) The Public Order of Ocean Resources: A Critique of the Contemporary Law of the Sea, MIT Press.

Hans Reiss (ed.) (1970) Kant's Political Writings, Cambridge University Press.

Paul Ricoeur (1992) Oneself as Another, Chicago University Press.

Thomas Risse, Stephen Ropp and Kathryn Sikkink (eds) (1999) The Power of Human Rights: International Norms and Domestic Change, Cambridge University Press.

Jonathan Schell (1982) The Fate of the Earth, Picador.

Carsten Stahn (2007) 'Responsibility to Protect: Political Rhetoric or Emerging Legal Norm?' 101 American Journal of International Law 99.

Jane Stromseth (2003) 'Rethinking Humanitarian Intervention: The Case for Incremental Change', in JL Holzgrefe and RO Keohane (eds), Humanitarian Intervention: Ethical, Legal, and Political Dilemmas, Cambridge University Press.

Peter Sutch (2001) Ethics, Justice, and International Relations: Constructing an International Community, Routledge.

Richard Tuck (1999) The Rights of War and Peace, Oxford University Press.

Michel Veuthey (2003) 'Public Conscience in International Humanitarian Action' 22 Refugee Survey Quarterly 197. 